\begin{tabular}{c|c|c|}
\cline { 3 - 3 } CRITICAL & $\begin{array}{l}\text { Western Ghats } \\
\text { EARTNERSHIP FUND }\end{array}$ \\
${ } }$
\end{tabular}

\title{
COMMUNITY AND CONSERVATION RESERVES IN SOUTHERN INDIA: STATUS, CHALLENGES AND OPPORTUNITIES
}

ISSN

Online 0974-7907 Print 0974-7893

\author{
Arun Kanagavel ${ }^{1}$, Revati Pandya ${ }^{2}$, Cynthia Sinclair ${ }^{3}$, Aditya Prithvi ${ }^{4}$ \& Rajeev Raghavan ${ }^{5}$ \\ 1,2,3 Wildlife Information Liaison Development Society (WILD), 96, Kumudham Nagar, Vilankurichi Road, Coimbatore, \\ Tamil Nadu 641035, India \\ ${ }^{4}$ Department of Econometrics, University of Madras, Tholkapiar Campus, Chepauk, Chennai, Tamil Nadu 600005, India \\ ${ }^{1,5}$ Conservation Research Group (CRG), St. Albert's College, Banerji Road, Kochi, Kerala 682018, India \\ ${ }^{5}$ Systematics, Ecology \& Conservation Laboratory, Zoo Outreach Organization (ZOO), 96 Kumudham Nagar, \\ Vilankurichi Road, Coimbatore, Tamil Nadu 641035, India \\ ${ }^{1}$ arun.kanagavel@gmail.com (corresponding author), ${ }^{2}$ revati.pandya@gmail.com, ${ }^{3}$ sinclair.cynthia@gmail.com, \\ ${ }^{4}$ solar.ads@gmail.com, ${ }^{5}$ rajeevraq@hotmail.com
}

Abstract: Community Reserves and Conservation Reserves illustrate a community-based co-management model, a first of its kind within the protected area (PA) network of India. Such reserves mark a shift towards an inclusive and decentralised approach within PAs in the country. Three such reserves in southern India: the Aghanashini Lion-tailed Macaque Conservation Reserve, Kadalundi-Vallikunnu Community Reserve and Thirupaddaimaradur Conservation Reserve, were selected to examine the reasons for their creation, management and stakeholder dynamics, with an aim to review their productivity and potential replicability. The study was carried out through semi-structured interviews with Forest Department officials, local community members and researchers working in the three reserves. Insufficient interaction between the stakeholders appeared to be a common issue in two reserves. The functioning of the reserves was also influenced, and in some cases negatively affected, by local politics. Financial stability was crucial in the functioning of reserves, as was consistency in interaction and appropriate monitoring of management plans. These elements are recommended for sustaining such reserves and creating communitybased management systems for conservation, to support an inclusive approach to PA management.

Keywords: Aghanashini, Forest Department, Kadalundi-Vallikunnu, local community, non-governmental organization, researcher, stakeholder assessment, Thirupaddaimaradur, Western Ghats.

DOI: http://dx.doi.org/10.11609/JoTT.03541.5256-65

Editor: Anonymity requested.

Date of publication: 26 December 2013 (online \& print)

Manuscript details: Ms \# 03541 | Received 27 February 2013 | Final received 10 December 2013 | Finally accepted 11 December 2013

Citation: Kanagavel, A., R. Pandya, C. Sinclair, A. Prithvi \& R. Raghavan (2013). Community and conservation reserves in southern India: status, challenges and opportunities. Journal of Threatened Taxa 5(17): 5256-5265; http://dx.doi.org/10.11609/JoTT.03541.5256-65

Copyright: @ Kanagavel et al 2013. Creative Commons Attribution 3.0 Unported License. JoTT allows unrestricted use of this article in any medium, reproduction and distribution by providing adequate credit to the authors and the source of publication.

Funding: The study was undertaken with financial support from the Critical Ecosystem Partnership Fund (CEPF)-Western Ghats Small Grants Program through the Ashoka Trust for Research in Ecology and Environment (ATREE), Bengaluru, India.

Competing Interest: Authors declare no competing interest. Funders had no role in study design, collection and interpretation of data and manuscript writing. One of the authors (CS) is currently working with CEPF-ATREE. However she was not associated with this organization, during the time, the study was carried out.

Author Contribution: AK and RR were involved in designing the study. AK, CS, AP and RR undertook the surveys. AK, RP, CS, AP and RR were involved in manuscript preparation.

Acknowledgements: The first author would like to thank Bhaskar Acharya, Vijayalakshmi, P.A. Kanagavel, Anvar Ali and Shrinivas Kadabagere for their help and support during the study: Varun Vikraman for volunteering on the surveys and Sethu Parvathy for her suggestions on the manuscript. The second author would like to thank Mamata Pandya for her comments on the manuscript. The authors would like to thank the two anonymous reviewers and the Subject Editor for their comments and suggestions that have improved this article.
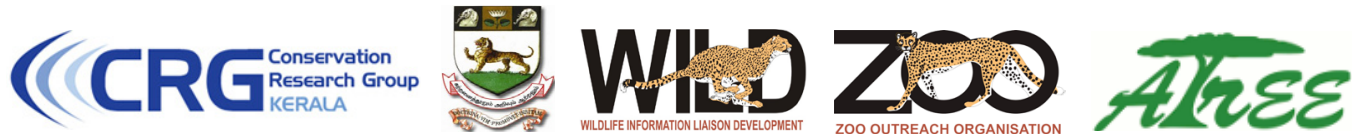

This article forms part of a special series on the Western Ghats of India, disseminating the results of work supported by the Critical Ecosystem Partnership Fund (CEPF), a joint initiative of l'Agence Française de Développement, Conservation International, the European Commission, the Global Environment Facility, the Government of Japan, the MacArthur Foundation and the World Bank. A fundamental goal of CEPF is to ensure civil society is engaged in biodiversity conservation. Implementation of the CEPF investment program in the Western Ghats is led and coordinated by the Ashoka Trust for Research in Ecology and the Environment (ATREE). 


\section{INTRODUCTION}

Protected areas (PA) for biodiversity conservation based on the preservationist principle have affected millions of people and their livelihoods in India over the past 40 years (Madhusudan \& Raman 2003; Wani \& Kothari 2007). More than 100,000 people have been relocated in various parts of the country for the creation of PAs and denied access to traditional lands and resource-use (Kothari et al. 1996, cited in Wani \& Kothari 2007). Forced relocations have morphed into induced relocation procedures wherein communities have no real choice, since a driving factor-such as severe restriction on resource usage-induces them to accept resettlement packages (Lasgorceix \& Kothari 2009). A further five million people in India face eviction due to policy amendments (Kothari 2004, cited in Brockington et al. 2006). Moreover, adoption of the recent Indian Wildlife (Protection) Amendment Act 2006 will see an increase in these figures, as it calls for resettlement of people, including indigenous people, from areas that are found to be critical tiger habitats (MoEF 2010a).

In synchrony with international mechanisms, there has been an increasing focus in India to integrate local communities into biodiversity conservation (MoEF $2010 a, b)$ through the setup of various policies that assist communities in sustaining livelihoods without compromising biodiversity conservation (Pathak et al. 2006). The National Forest Policy of 1988 and Joint Forest Management guidelines helped set up the Joint Forest Management programme which supports local livelihoods and conservation of natural resources. The Panchayat (Extension to the Scheduled Areas) Act, 1996, empowers local traditional institutions by allowing them to decide and participate in the governance of issues concerning the utilisation of non-timber forest produce (NTFP). The Scheduled Tribes and other Traditional Forest Dwellers (Recognition of Forest Rights) Act, 2006 recognises the rights of forest-dwelling communities and empowers them with land-entitlement, utilisation of natural resources within PAs and informed consent during resettlement procedures. The Biological Diversity Act 2002 and the Wildlife Action Plan (2002-2016) strengthen the role of communities in the utilisation and management of biodiversity both within and outside PAs. The most promising of these official initiatives is the Wildlife (Protection) Amendment Act, 2002, which allows for the creation of Conservation Reserves and Community Reserves as a third type of formal PA other than National Parks and Wildlife Sanctuaries (MoEF 2010c; Kanagavel et al. 2013).

\section{Community Reserves and Conservation Reserves}

Conservation Reserves (IUCN Category VI) are community co-managed biodiversity rich areas, which are particularly close to existing PAs and serve as a buffer and/or corridor to establish a continuous PA network. Conservation Reserves can be declared only on government-owned lands (MoEF 2010c). Community Reserves (IUCN Category V) on the other hand can be set up on biodiversity abundant lands that are privately or community-owned, and are managed by the individual(s)/communities in possession of the area. Both these reserves allow for extraction of natural resources, the levels of which are governed by a multistakeholder Reserve Management Committee (MoEF 2010c).

A Conservation Reserve Management Committee must consist of representatives from the local village Panchayat, non-governmental organisations (NGOs), and the Department of Agriculture and Animal Husbandry. Similarly, a Community Reserve Management Committee is to consist of five representatives nominated by the local Village Panchayat or the Gram Sabha, and one representative each from the State Department of Forest and Wildlife. A chairman would be elected by the committee who would also serve as a Wildlife Warden of the reserve (MoEF 2010c).

These reserves mark a shift towards a more inclusive and decentralised approach within the PA network, where the management entails participation of multiple stakeholders, which is the emphasis of communitybased management (Agrawal \& Ribot 1999; Ribot 2004).

There are more than 58 Conservation Reserves in India, 34 of which are concentrated in Jammu and Kashmir (WII 2010a). The Tiruppadaimarathur Conservation Reserve in Tamil Nadu, a $0.03 \mathrm{~km}^{2}$ heronry, is the smallest of its kind (TFD 2007). The largest is the $299.52 \mathrm{~km}^{2}$ Aghanashini Lion-tailed Macaque Conservation Reserve in Karnataka, which has the largest population of these 'Endangered' macaques in the world (Kumara et al. 2008). There are currently five community reserves in India (WII 2010b) of sizes ranging between $1.5 \mathrm{~km}^{2}$ (Kadalundi Community Reserve, Kerala; The Hindu 2007) and $12.67 \mathrm{~km}^{2}$ (Lalwan Community Reserve Punjab; DFWP 2010).

Kokare Bellur Community Reserve, Aghanashini Lion-tailed Macaque Conservation Reserve, Bedthi Conservation Reserve, Hornbill Conservation Reserve and Shalmala Riparian Ecosystem Conservation Reserve in Karnataka, and the Bhorkada Conservation Reserve in Maharashtra together encompass $420.59 \mathrm{~km}^{2}$, representing $0.0025 \%$ of the entire Western Ghats. In 
spite of a large number of such reserves existing in the country, very little information is available concerning why they were set up, what their management approaches are, and what interactions exist among their stakeholders. Through this study, carried out in two conservation reserves and one community reserve in southern India, we attempt to fill this knowledge gap by trying to understand the management approaches adopted, interactions between stakeholders, challenges faced and potential opportunities.

\section{MATERIALS AND METHODS}

The study was carried out during January and February 2012. Interviews were conducted with local communities, conservation researchers and Forest Department (FD) officials in three reserves located in different states in southern India, viz., the Aghanashini Lion-tailed Macaque Conservation Reserve (ACR) in Karnataka, Kadalundi-Vallikunnu Community Reserve $(K C R)$ in Kerala and Thirupaddaimaradur Conservation Reserve (TCR) in Tamil Nadu (Fig. 1).

\section{Aghanashini Lion-tailed Macaque Conservation Reserve}

This reserve located in the Sirsi-Honnavarra Forest Division of the Uttara Kannada District, Karnataka supports the largest population of the 'Endangered' Lion-tailed Macaque Macaca silenus, comprising more than 500 individuals in 31 groups (Kumara et al. 2008). In 2008, a plan was submitted to the Principal Chief Conservator of Forests, Department of Forest and Wildlife, Karnataka, and the Western Ghats Task Force Committee to declare the area as a Conservation Reserve (Kumara 2011). The Deputy Conservator of Forests, Karnataka resubmitted a new proposal that included new sensitive areas along the Aghanashini River, prioritised through detailed surveys that incorporated the occurrence of threatened and endemic species, critical corridors and threats (Dandekar 2011; Kumara 2011). The reserve reportedly faced initial opposition from politicians towards establishment due to confusion over resource-utilization rights by local communities (The Times of India 2010). On 13 June 2011 , the reserve spanning across $299.52 \mathrm{~km}^{2}$ was formally declared and was to be managed in collaboration with the FD and gram panchayats without restricting resource use (The Times of India 2010; Kumara 2011).

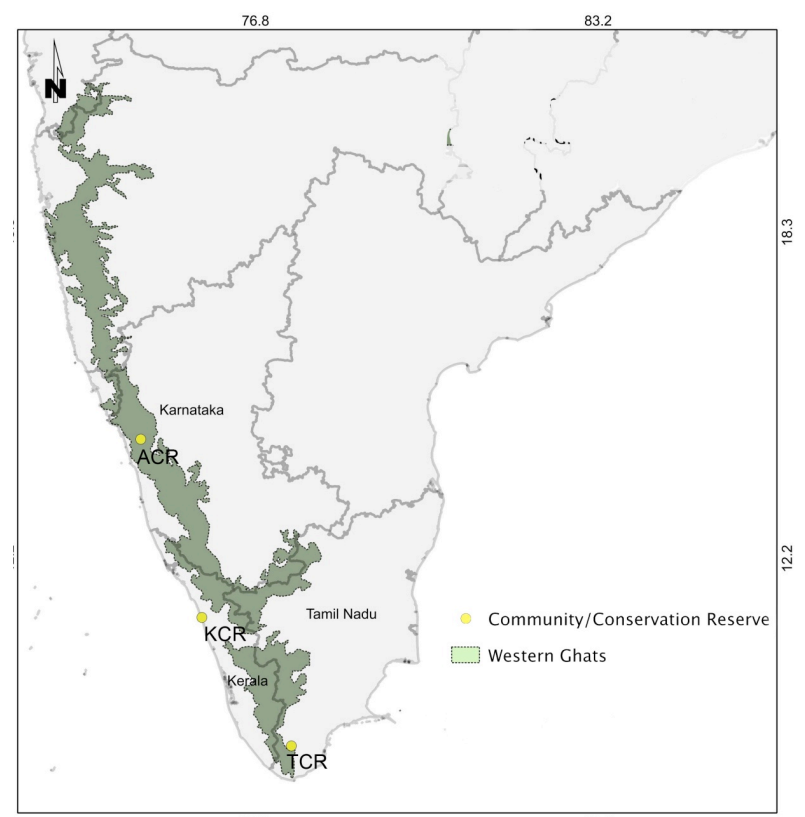

Figure 1. The three Conservation/Community Reserves in south India (abbreviations as in text) surveyed in the present study

\section{Kadalundi-Vallikunnu Community Reserve}

Spread across $1.5 \mathrm{~km}^{2}$, the Kadalundi-Vallikunnu estuary located in Kozhikode (Calicut) and Malappuram districts of Kerala State is the first Community Reserve of India, declared in 2007 (Chitharanjan 2011). A wintering ground for migratory birds; nearly 110 species of avifauna including the 'Critically Endangered' Spoonbilled Sandpiper Eurynorhynchus pygmeus, Lesser Sand Plover Charadrius mongolus, Bar-tailed Godwit Limosa lapponica and Crab Plover Dromas ardeola have been recorded at this estuary which is surrounded by patches of mangroves (The Hindu 2007; Aarif et al. 2011; Images 2,3 ). The estuary faced several threats from sand mining, dumping of wastes, coir retting (the process of segregating fibre found in coconut husks out of coir; see Rajan \& Abraham 2007), defoliation, collection of oysters and mussels, as well as infrastructure development (Remani et al. 1989; Nair 2007; Aarif et al. 2011). The Kadalundi-Vallikunnu Community Reserve (KCR) was set up not only to reduce these threats but also to promote it as a birding destination and improve local livelihoods through tourism (Nair 2007; The Times of India 2011). The government reaffirmed that the reserve would not pose a threat to local livelihoods and would promote community participation (The Hindu 2009a). Activities like setting up of rest houses, watch towers for bird watching, a museum on mangroves and boating were part of the management plan. Tourist guides were also to be engaged from the local communities. A coir 


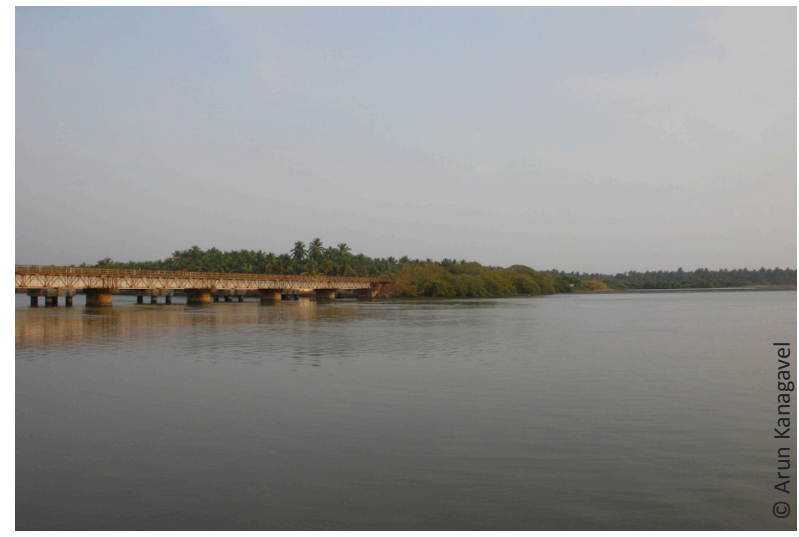

Image 2. The estuary flanked by the railway line, mangrove and coconut plantations at the Kadalundi-Vallikunnu Community Reserve

factory outside the mangrove area was started by the KCR management committee to compensate for loss of livelihood opportunities after the formation of the reserve.

The Reserve Management Committee headed by the Kadalundi Panchayat is managed by six members, three from the Vallikunnu Panchayat, two from Kadalundi Panchayat and a forester from the Thamarassery range of the Kerala Forest Department (The Hindu 2009b). The official formulation of this committee reportedly took two years due to a power struggle between the Kadalundi and Vallikunnu panchayats which was resolved after the intervention of the Forest Minister of Kerala, as per which it was decided that the chair of the committee would be rotated between the two Panchayats (Protected Area Update 2008; The Hindu 2009b). In the year 2009, funds were reportedly released by the central government to formulate reserve management plans to realise the above-mentioned aims after conducting a participatory rural appraisal (PRA) with the local communities (see The Hindu 2009c). However, the formulated management plan was reportedly not accepted by the state government and these initiatives have not yet begun (The Times of India 2011).

\section{Thirupaddaimaradur Conservation Reserve}

This reserve, around thevillage ofThirupaddaimaradur is situated on the banks of the river Thamirabarani, $30 \mathrm{~km}$ away from the city of Tirunelveli in Tamil Nadu. This was the first Conservation Reserve in India, set up in 2005 to primarily protect birds around the village (The Hindu 2005). The reserve which serves as a nesting ground for 200-400 pairs of Painted Storks Mycteria leucocephala and egrets is managed reportedly by a committee composed "of the public, forest department, NGOs, scientists, member of the legislative assembly

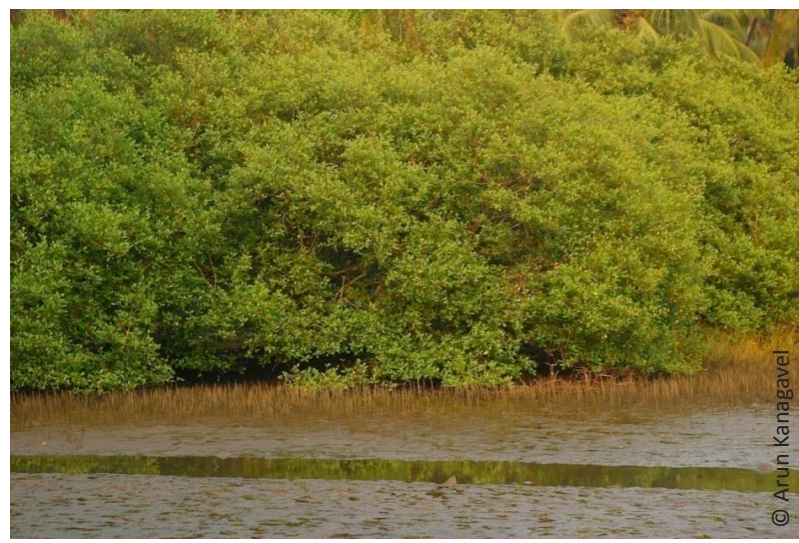

Image 3. Mangroves at the Kadalundi-Vallikunnu Community Reserve

(MLA) and the Panchayat president" (The Hindu 2005). With the reforestation initiative undertaken by the FD, which included participation from the local community, and initiatives of the panchayat such as banning the use of firecrackers and rehabilitating chicks that fall off nests, the conservation regime at the reserve has begun to improve (Images 4,5). Awareness campaigns and exposure visits for the local communities to the community-managed Koonthankulam Bird Sanctuary, Tirunelveli District, undertaken by the FD helped to improve their understanding of community-based conservation.

\section{Methods}

At ACR, one FD official, two locals and a team of three representatives from a local NGO were interviewed. At KCR, two FD officials, four locals (two each from Kadalundi and Vallikunnu) and two researchers were interviewed. At the TCR, two FD officials, two local community members and two researchers were interviewed. The researchers interviewed were those who had visited, worked, or were working either in the reserve or in the larger landscape.

Interviews were mostly undertaken in person, wherein they were recorded using a digital recorder and transcribed. In cases where it was not possible to meet respondents in person, either telephonic interviews or interviews via electronic mail were undertaken. Given the lack of basic information on the management of these reserves, semi-structured interviews (Appendix 1) with open-ended questions that allowed for detailed discussion were used. The respondents were first asked to describe the reserve and the reason for its setup. The role of the concerned stakeholder in the reserve and the roles of other stakeholders and their interaction with them were then inquired. Specific questions were 


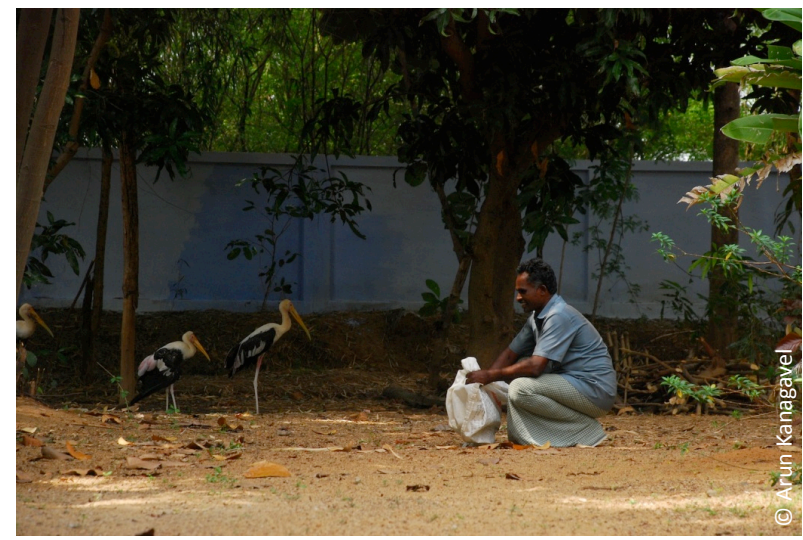

Image 4. The forest department staff employed from the local community feeding juvenile painted storks rehabilitated at the Thirupaddaimaradur Conservation Reserve

asked regarding whether and how the FD officials, researchers and local communities were involved in reserve declaration. The respondents were then asked about reserve management, people involved in the management, how management plans were decided, and how the reserve management committee was chosen. Information on the frequency of committee meetings was also sought. Finally, respondents were asked to provide information on any difficulties that were faced with respect to the establishment or running of these reserves and whether they had any suggestions which could help in the setting up and implementation of similar reserves, elsewhere.

The stakeholder interviews were summarised as per specific issues. Any difference in perceptions within and among stakeholders have been highlighted.

\section{RESULTS}

While two reserves (TCR, KCR) were set up to conserve the area from localised threats, one (ACR) was set up against the possible construction of a dam. While two of the reserves (TCR, KCR) were set up to conserve the bird diversity, the third (ACR) was set up to conserve a threatened primate and specialised ecosystems. Only one (ACR) was set up after rigorous prioritization based on ecological parameters. While KCR was setup to improve livelihoods through tourism, tourism initiatives at TCR and ACR were targeted following reserve declaration. Two (ACR, KCR) of the reserve facilitators conducted a PRA with local communities before they were declared. Both ACR and KCR faced initial hurdles from local communities and politicians. At two reserves (KCR and TCR), which were set up nearly five years ago,

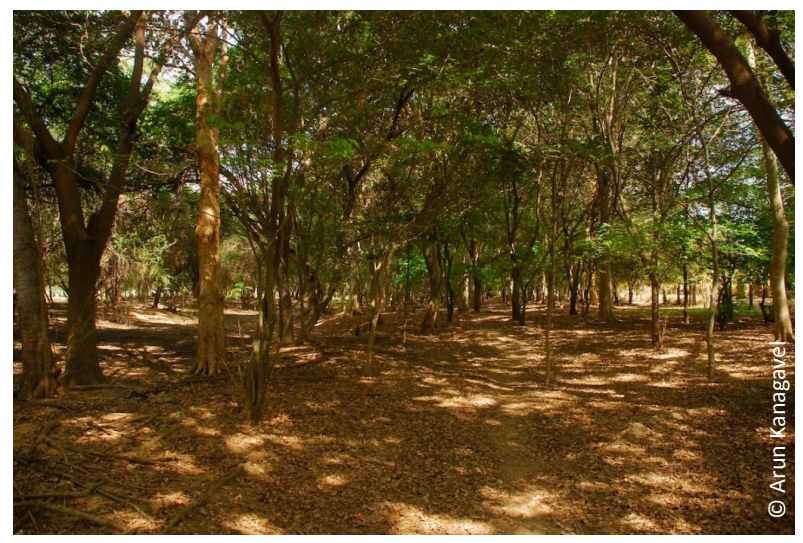

Image 5. The resultant vegetation of the decade-long planting initiative at the Thirupaddaimaradur Conservation Reserve

stakeholder interaction was absent, and the form of participation by local communities was largely that of abstaining from resource use.

\section{Aghanashini Lion-tailed Macaque Conservation Reserve (ACR)}

ACR was identified by designating potential sites based on their forest cover, priority species and ecosystems, and a threat index from across the district of Uttara Kannada. It aimed to protect the Lion-tailed Macaque, Myristica swamps and newly described amphibian species and the entire landscape from the impending threat of dams. PRA and community mapping were undertaken by the respondents to understand the occurrence of priority species, types and utilization of NTFPs, changes in the area over time, human-animal conflicts, and, the perceptions of local communities towards conservation and the sites they would like to protect. The resulting information on the ecological, and primarily the economic benefits of conserving the priority sites were conveyed to decision makers.

Non-governmental organisations (NGO) lobbied for the formation of the reserve through presentations made to several state ministers including the Forest Minister and Chief Minister of the Government of Karnataka, and with support from the Director of the Tiger Task Force, the area was declared as a Conservation Reserve.

Our surveys revealed that while one respondent from the local community was aware of reserve demarcation since the NGO had approached the individual and discussed the plans of the FD and their organization's, another was unaware. A continuous association of over 30 years through empowering the local communities in sustainably harvesting NTFPs and value addition assisted the NGO team in garnering the participation of local 
communities. The reserve is currently in the process of setting up its management committee, which would consist of representatives from the local community, FD and the relevant NGO. Two such committees would be chosen to manage the lower and upper part of the reserve, as the spatial distance would make it difficult for locals from both parts of the reserve to meet at a common place. Interested local individuals would be chosen as committee members from the Village Forest Committee and Joint Forest Management Committee.

Local respondents stated that they mainly depended on the forests for firewood, which remained unaffected after the reserve declaration. The local respondents' contribution to the conservation of the reserve was by abstaining from hunting and tree felling and informing officials about offences. The members of the NGO stated that the priority of local communities was not in conserving tigers but the sustainable use and conservation of NTFPs and issues like education and health. They however stated that the FD was not very interested in collaborative management and some officials may not be willing to convert Reserve Forests to protected areas with enhanced protection, as it would lead to a loss of benefits for the FD.

Both respondents from the local community stated that there was minimum interaction with the FD, and that the FD officials walked through the settlements once in a while and distributed money to them under the Joint Forest Management program. On the other hand, the FD respondent stated that their responsibility was to serve as the administrator of the reserve, which was a joint effort between them and the local communities, and that the FD would provide support to local communities in undertaking conservation activities.

\section{Kadalundi-Vallikunnu Community Reserve (KCR)}

All the respondents were aware of the purpose behind the establishment of the reserve, as an attempt to protect the estuarine biodiversity. However, the researchers who were interviewed perceived that the reserve was also set up to reduce resource utilization, primarily of mangroves since the locals wanted to fell them in their land, thereby protecting the avifauna and associated tourism. In contrast, the FD official stated that the reserve was setup to safeguard local livelihoods while attempting to improve the estuary in parallel. The respondents stated that bird watchers, "environmental lovers", Panchayat, NGOs, FD, the Kozhikode District Collector and state government were involved in declaring the reserve. The researchers stated that local communities were not interested and protested against the reserve declaration due to the assumption that their resource utilization would be restricted.

The respondents' views towards reserve ownership differed. While the FD stated that the reserve land belonged to private individuals and only the river belonged to the FD, local communities stated that the land belonged to them, while a researcher stated that both the government and panchayat owned the land. The local community was indeed part of a PRA exercise wherein individuals living within $200 \mathrm{~m}$ of the estuary were inquired about land ownership, their education qualification and livelihoods. It was stated that the reserve boundary was demarcated by the FD based on the availability of the mangroves and land availability, with little input from the local community.

Most of the respondents stated that resource extraction was not curbed after the reserve establishment. One of the researchers stated that resource utilization had not changed but coir retting was discontinued, whereas the other researcher stated that hunting and coir retting were "stopped" while "sand mining and fishing continued". The former also stated that fish and avian diversity had reduced probably due to land-use changes and spread of mangroves.

While half of the respondents knew that a committee managed the reserve, one individual from the local community stated, "There is no management. Nothing has been done here". Similarly one of the researchers claimed to have no idea of its existence and the other researcher stated that the communities did not support the committee since their perceptions were not considered; they did not have any role and was nominated by the government and not by them. It was stated that since the PRA exercise, no other activities have been undertaken at the reserve and the Government did not accept the draft management plan.

The much-publicised difference between the Kadalundi and Vallikkunnu panchayats during the reserve committee's formulation was stated as due to the panchayats being managed by opposing political parties. Since most of the area of the reserve fell within Vallikunnu, this panchayat demanded for a larger representation in the committee. However it was decided that there would be equal representation from both panchayats and that the chairman would be elected from Kadalundi, which led to the reserve's nonfunctional state from an imbalance of power. Moreover, it was stated that currently the committee was led by the opposition political party, which was why the ruling party wanted to dissolve the existing committee.

The committee is said to have employed two to four 
guides/watchers from the local communities whose salaries had not been paid to date. Local communities stated that they had no role in the management of the area while the FD official stated that no stakeholder was currently involved in the reserve's management due to unavailability of funds. While one researcher stated that there was no specific role for the local community towards the management, another pointed out that being part of the committee represented their aspirations but activities needed to be generated to foster their role. Members of the local community felt that the FD had to do more work to make the reserve functional, and though they did not have any expectations from the reserve, they did not want to lose rights over their land and resources. They also perceived that there was no relationship with the $F D$, since there was no activity in the reserve. A researcher said that there was no regular interaction between the local stakeholders and FD, who did not make any significant contribution other than setting up sign boards and conducting workshops with students.

\section{Thirupaddaimaradur Conservation Reserve (TCR)}

The primary reason for reserve declaration was the intensive sand mining undertaken by locals and outsiders on the riverbanks, which threatened the safety of the village, as the sand functioned as a barrier when the river flooded. Secondly, the trees around the village supported numerous resident and migrant birds including Asian Openbill Anastomus oscitans, Black-headed Ibis Threskiornis melanocephalus and cormorants Phalacrocorax spp. that nest in large numbers. Only local communities cited the former reason whereas the latter, which was instrumental in its declaration as a Conservation Reserve, was stated by all the stakeholders. A retired Supreme Court Judge, a resident of the village was stated to have played a pivotal role in the area's declaration as a Conservation Reserve. A local respondent stated that the Judge and the Principal Chief Conservator of Forests aided in reserve declaration, while the respondent contributed by providing a checklist of avifauna.

Although, initiatives of tree planting to prevent soil erosion began in 1996, it became successful only after 1999 with financial assistance from the Judge and the provision of saplings by the FD. Post reserve declaration, another planting initiative was taken up, which was managed by two staff from the local community employed by the FD, who also monitored the reserve and guided tourists. Except for small quantities for use by the local community, sand mining was subsequently discontinued. Respondents from the local community stated that they contributed to reserve management by not hunting birds, initiating fires or using firecrackers, and disallowed outsiders from such activities. A respondent from the FD also supported this statement, but argued that firecrackers had not reduced and their use during festivals and special occasions resulted in reduced avian abundance. The locals were also involved in rescuing chicks that fell out of nests, which were subsequently rehabilitated by the FD at the residence of the Judge in the village.

While one individual from the community stated that grazing had stopped after reserve declaration, the other stated the reverse. A FD respondent mentioned that grazing was the biggest problem to the reforestation initiative, and that fines were imposed on livestock owners to reduce it in the reserve limits. Fencing was also initiated especially to protect freshly planted saplings. De-fencing was undertaken when the plants had grown sufficiently.

A reserve management committee consisting of the local community and FD was set up. The local respondents stated that village elders as well as the panchayat head represented the local community in the committee, whose meetings were conducted the village temple. Since 2005, there had been two meetings but none in the last five years. The FD officials stated that due to a lack of funds there was nothing to be discussed by the committee. The FD had previously provided loans to the locals through the village forest committee, which was subsequently discontinued. It was stated that the judge financially supported numerous initiatives in the reserve including the provision of basic salaries for the forest watcher who was not on the permanent payroll of the FD until recently.

Local respondents felt that getting the village declared as a Conservation Reserve had been largely beneficial for them, as tourism had improved their local economy and brought recognition to their small village. To help tourists, a small guesthouse, financially supported by the judge was also constructed. More such amenities, like watchtowers and benches in the temple premises, have been proposed to be built, when funds are available.

Researchers helped document the biodiversity and formulate the Reserve Management Plan. They are currently involved in assessing bird diversity, in conservation education and in bat surveys with the participation of local children. 


\section{Current and future challenges}

The challenges commonly faced at all the three reserves were the lack of appropriate interaction between the local communities and FD, absence of a follow up to management plans, consequential arguments among stakeholders on the lack of their execution and unstable revenue. A local respondent from ACR mentioned that there was an increase in tourists from urban areas which was a menace to them.

Specifically, the respondents stated that politicians disturbed the functioning of KCR, which was referred to as a "paper park". In this reserve, no scientific mechanisms existed for the sustainable utilization of natural resources that it allowed for. There was a lack of facilitators to solve issues within and among stakeholders. Garbage was disposed off within the reserve boundaries and one of the respondents stated "the local communities lack awareness about the cons of such disposal".

\section{Suggestions for setting up similar reserves}

Respondents stated that facilitators should know the landscape, concerned local communities and the FD well, and maintain a good relationship with stakeholders. Before reserve declaration, relevant stakeholders need to be identified. Avenues for capacity building for local communities and their organizations (panchayat) need to be opened, and empowered through the provision of opportunities. Opportunities and incentives (like ecotourism, value addition of NTFPs) need to be created for local communities to participate in the management. Local communities cannot always be expected to participate in an initiative which may not give them any benefits. The members of the reserve committee should also have access to a regular source of income. Political involvement in the reserve should be kept to a minimum, and for declaring such a reserve the government could be approached with a motivated and mobilized citizen group.

As a researcher pointed out "factors like threat index, ecological and corridor values may not be relevant to the common man living inside the reserve". Since the priority of stakeholders differed, one needed to approach each of them differently, not only through an ecological rationale, but a socio-economic one as well. $A$ respondent from KCR suggested that such reserves in general should not be declared if they were to be inactive, reduced to "paper parks" and being a financial burden on the government.

\section{DISCUSSION}

Care needs to be exercised while extrapolating the results of this study to other Community Reserves and Conservation Reserves in India, given that this study only deals with a few such reserves in southern India and involves a small sample of respondent stakeholders.

In two out of three reserves, there was major support from local communities. There was an absence of dedicated financial support for these PAs. Protected areas like Community and Conservation Reserves need continuous, year-round financial support due to their collaborative nature, which in order to sustain, requires periodical stakeholder-meetings and monitoring of the initiatives set up. A system of trust funds and ensuring an inflow of money to these funds from livelihood initiatives like tourism or private donors (McNeely 1994) could ensure much-needed financial sustainability that these reserves lack. Tourism initiatives have been proposed at all the three surveyed reserves to engage the community and generate income for them as well as the reserve. However, this needs to be carefully assessed since the financial input from tourism varies among PAs and could support their management only in certain cases (Karanth \& DeFries 2011), and also because tourism has potentially negative environmental and social impacts, which need to be carefully managed. Promising livelihood options to local communities needs to be done sensitively. The attitude of local communities towards KCR could have resulted from such promises not being fulfilled.

Recognition of differences within local communities and among stakeholder interests, including those within the management committee is vital. This aids in local involvement in management and conflict resolution to effectively manage PAs (McNeely 1994; Agrawal \& Gibson 1999). At TCR for example, the perceived goal for reserve creation was not entirely consistent among all stakeholders.

Political differences have affected the formation and functioning of the reserve management committee at KCR where such differences surfaced when the committee was to be formed and, continued thereafter. If the local panchayats are to be a part of reserve management, the tenure of such stakeholders in the committee should be set accordingly. In the case where two or more panchayats are involved, adequate representation must be allocated based on the extent of the reserve within the respective panchayats. Also, monitoring the management committees' functionality would need to be a part of the protocol since its formation. 
The reserve management committee has the freedom of creating the management plan with the help of its committee members. This, however, calls for developing protocols for stakeholder interactions, which would aid in the efficient implementation and management of committee plans. Multi-stakeholder management committees enable initiation of such interaction, yet the productivity and sustainability of the same depends on stakeholder interest and incentives. While collaborative management within other PAs (national parks and sanctuaries) may not exist officially there have been initiatives in this regard, based on stakeholder interest and trust. At Periyar Tiger Reserve in Kerala, for example, reserve officials have worked with the villagers to develop employment opportunities through community-managed ecotourism (Lockwood et al. 2006). Villagers have also voluntarily taken up patrolling the reserve, managing tourist inflow and using traditional skills and systems to manage various initiatives. Reserve officials have considered integrating villagers into reserve management.

Consistency in interactions prior and subsequent to the formation of the committee also needs to be considered and monitored. Effective governance of forest resources is also based on frequent stakeholder interaction, which aids in building trust among them (Singh \& Pandey 2010).

Effective resource governance is also based on formulating rules, monitoring and enforcement by local communities (Singh \& Pandey 2010). A Joint Forest Management initiative in the Deulgaon community, Maharashtra State, India, involved management norms formed by the locals, which led to improved monitoring. Norms like resource extraction limits and prohibition were complied with, as the governance was based on strict monetary sanctions and the penalties were decided by the executive committee (Ghate \& Nagendra 2005).

\section{CONCLUSION}

The Western Ghats-Sri Lanka Hotspot is the most densely populated biodiversity hotspot (Cincotta et al. 2000) in the world with the presence of numerous forestdwelling communities, and, Community Reserves and Conservation Reserves provide opportunities to promote effective conservation by including local communities in PA management rather than excluding them. This may avoid exhausting scarce financial resources through expensive resettlement programmes and the creation of conservation refugees in the process, and could help rectify the negative effects that PAs have had on local communities (Mulongoy \& Chape 2004). The multistakeholder component of reserve management needs to be monitored, interactions between stakeholders maintained and their livelihoods supported in accordance with the management plans. The most critical challenge remains financial sustainability, which must be ensured for such reserves to be functional.

\section{REFERENCES}

Aarif, K.M., P.K. Prasadan \& S. Babu (2011). Conservation significance of the Kadalundi-Vallikkunnu community reserve. Current Science 101(6): 717-718.

Agrawal, A. \& C. Gibson (1999). Enchantment and disenchantment: the role of community in natural resource conservation. World Development 27(4): 629-649.

Agrawal, A. \& J.C. Ribot (1999). Accountability in decentralization: a framework with South Asian and West African cases. Journal of Developing Areas 33: 473-502.

Brockington, D., J. Igoe \& K. Scnhmidt-Soltau (2006). Conservation, human rights, and poverty reduction. Conservation Biology 20: 250252; http://dx.doi.org/10.1111/j.1523-1739.2006.00335.x

Chitharanjan (2011). Kadalundi reserve all set to lure nature lovers. The Times of India.http://articles.timesofindia.indiatimes.com/201109-06/kozhikode/30118701_1_migratory-birds-kadalundi-birdsanctuary (accessed 15 February 2013).

Cincotta, R.P., J. Wisnewski \& R. Engelman (2000). Human population in the biodiversity hotspots. Nature 404: 990-992.

Dandekar, P. (2011). Novel Conservation reserves on Kali, Bedthi and Aghanashini in the Western Ghats. South Asian Network on Dams, Rivers and People, Delhi. http://sandrp.in/rivers/Novel_ Conservation_reserves_on_Kali_Bedthi_and_Aghanashini_in_the Western_Ghats.pdf/view?searchterm=Novel\%20Conservation $\% 20$ reserves\%20on\%20Kali,\%20Bedthi\%20and\%20Aghanashini\%20 in\%20the\%20Western\%20Ghats (accessed $9^{\text {th }}$ January 2013).

DFWP, Punjab (Department of Forests \& Wildlife Preservation, Punjab) (2010). Wildlife Protected Areas. DFWP, Punjab. Available from http://www.pbforests.gov.in/Pdfs/statistics/6\%20Wildlife\%20 Protected\%20Areas.pdf (accessed 17 February 2013).

Ghate, R. \& H. Nagendra (2005). Role of monitoring in institutional performance: forest management in Maharashtra, India. Conservation and Society 3(2): 509-532.

Kanagavel, A., S. Joseph, R. Pandya \& R. Raghavan (2013). Potential for Community and Conservation Reserves in the Western Ghats, India. Asian Journal of Conservation Biology 2(1): 61-68.

Karanth, K.K. \& R. DeFries (2011). Nature-based tourism in Indian protected areas: New challenges in park management. Conservation Letters 4(2): 137-149; http://dx.doi.org/10.1111/ j.1755-263X.2010.00154.X

Kumara, H.N. (2011). Declaration of "Aghanashini Lion-tailed Macaque Conservation Reserve". Zoo's Print 26(7): 5.

Kumara, H.N., V.M. Raj \& K. Santhosh (2008). Assessment of important wildlife habitat in Sirsi-Honnavara Foert Divisions. Karnataka: with special emphasis on estimation of Lion-tailed Macaque (Macaca silenus) population. Technical Report 1, Submitted to Karnataka Forest Department, Sirsi.

Lasgorceix, A. \& A. Kothari (2009). Displacement and Relocation of Protected Areas:A Synthesis and Analysis of Case Studies. Economic \& Political Weekly xliv: 38-47.

Lockwood, M., G. Worboys \& A. Kothari (2006). Managing Protected Areas: A Global Guide. USA \& UK: Earthscan Publishing.

Madhusudan, M.D. \& T.R.S. Raman (2003). Conservation as if 
Biological Diversity Matters: Preservation versus Sustainable Use in India. Conservation and Society 1: 49-59.

McNeely, J.A. (1994). Protected areas for the 21st century: working to provide benefits to society. Biodiversity and Conservation 3(5): 390-405; http://dx.doi.org/10.1007/BF00057797

MoEF (Ministry of Environment and Forests, Government of India) (2010a). The Wildlife Amendment (Protection) Act 2006. MoEF, New Delhi. Available from http://www.fra.org.in/laws/wlact2.pdf (accessed 18 February 2013).

MoEF (2010b). State/Union Territory Minor Forest Produce (Ownership of Forest Dependent Community) Act, 2005. MoEF New Delhi. Available from http://moef.nic.in/downloads/rulesand-regulations/ownership_forest2005.pdf (accessed 18 February 2013).

MoEF (2010c). The Wildlife Amendment (Protection) Act 2002. MoEF, New Delhi. Available from http://www.envfor.nic.in/legis/wildlife/ wild_act_02.htm (accessed 18 February 2013).

Mulongoy, K.J. \& S. Chape (2004). Protected areas and biodiversity. An Overview of Key Issues. CBD Secretariat and UNEP-WCMC, Montreal, Canada and Cambridge, UK, 52pp.

Nair, R.M. (2007). Kadalundi-Vallikunnu community reserve rich in flora, fauna. http://www.hindu.com/2007/10/17/ stories/2007101753200500.htm (accessed 9 January 2013).

Pathak, N., T. Balasinorwala, A. Kothari \& B.R. Bushley (2006). People in Conservation, Community Conserved Areas in India. Kalpavriksh, Pune, India, 12pp.

Protected Area Update (2008). Conflict between panchayats over management of Kadalundi Community Reserve. Protected Area Update 76: 10

Rajan, A. \& E. Abraham (2007). Coir fiber-process and opportunities. Journal of Natural Fibers 3(4): 29-41.

Remani, K.N., E. Nirmala \& S.R. Nair (1989). Pollution due to coir retting and its effect on estuarine flora and fauna. International Journal of Environmental Studies 32(4): 285-295; http://dx.doi. org/10.1080/00207238908710469

Ribot, J.C. (2004). Waiting for Democracy: The Politics of Choice in Natural Resource Decentralization. World Resources Institute, Washington DC, 140pp.

Singh, V.S. \& D.N. Pandey (2010). What Makes Joint Forest Management Successful? Science-Based Policy Lessons on
Sustainable Governance of Forests in India. RSPCB Occasional Paper No. 3/2010, Jaipur: Rajastan State Pollution Control Board, 40pp.

TFD (TamilNadu Forest Department) (2007). Tiruppadaimarathur Conservation Reserve. TFD, tamil Nadu. Available from http://www. forests.tn.nic.in/wildbiodiversity/cr_tcr.html (accessed 9 January 2013).

The Hindu (2005). Conservation reserve planned in Tirunelveli village. http://www.hindu.com/2005/05/16/stories/2005051603910500. htm (accessed 9 January 2013).

The Hindu (2007). Estuary Declared Community Reserve. The Hindu http://www.hindu.com/2007/10/19/stories/2007101952950300. htm (accessed 9 January 2013).

The Hindu (2009a). Panel's assurance to people on project. http:// www.thehindu.com/todays-paper/tp-national/tp-kerala/ article372318.ece?css= print (accessed 9 January 2013).

The Hindu (2009b). Kadalundi representative chosen to head panel. http://www.hindu.com/2009/01/05/stories/2009010551210300. htm (accessed 9 January 2013).

The Hindu (2009c). Central Funds for community reserve. http://www. hindu.com/2009/04/29/stories/2009042952830300.htm (accessed 9 January 2013).

The Times of India (2010). Wildlife board Okays community conservation reserves. http://timesofindia.indiatimes.com/ city/bangalore/Wildlife-board-okays-community- conservationreserves/articleshow/6295489.cms - ixzzOwShi0voo (accessed 9 January 2013).

The Times of India (2011). Roadblock to Kadalundi development. http://articles.timesofindia.indiatimes.com/2011-11-21/ kochi/30425360_1_kadalundi-management-plan-plan-approval (accessed 9 January 2013).

Wani, M. \& A. Kothari (2007). Protected areas and human rights in India: the impact of the official conservation model on local communities. Policy Matters 15: 100-114.

WII (Wildlife Institute of India) (2010a). Conservation Reserves. WII, Dehradun. Available from http://oldwww.wii.gov.in/nwdc/cr.htm (accessed April 2010)

WII (Wildlife Institute of India) (2010b). Community Reserves. WII, Dehradun. Available from http://oldwww.wii.gov.in/nwdc/ community reserves.htm (accessed April 2010).

\section{Appendix 1. Interview Guide}

Please tell us about the reserve. (Please describe the biodiversity and ecosystem at this reserve. Who helped declare this reserve? Who does the reserve area belong to? Why has it been setup?)

How will the area benefit now?

Who are involved in the management of the reserve and what are their roles?

- Have local communities been involved while declaring the reserve? How?

Do local communties help in the management of the area? How?

Have researchers been involved while declaring the reserve? How?

Do researchers help in the management of the area? How?

Has the forest department been involved while declaring the reserve? How?

Does the forest department help in the management of the area? How?

- Have you or any other person from the local community been consulted during the reserve establishment process? What was enquired from you? (Local Community)

What are the local community's expectations from the reserve? (Local Community)

What sort of produce do you collect from the area? Did this change when the reserve was setup? (Local Community)

Please describe the research and outreach activities you have undertaken here. (Researcher) How has your interaction been with other stakeholders? (Forest Department, Local Community, Researchers)

- Who will decide how the reserve will be managed?

How were the management plans decided?

How were the reserve management committees chosen? How often do they meet?

What future activities are being planned for the reserve?

Have there been any difficulties?

-What are your suggestions when we implement such reserves in Theni?
Author Details: ARUN KANAGAVEL, keen on research that would inform conservation action, is interested in social dimensions that influence perception of nature and its conservation, and the potential of local communities in linking biodiversity conservation and protected areas. REVATI PANDYA is interested in natural resource management, its plurality and understanding the same through stakeholder perceptions as a basis for conflict resolution. In relation to this, she is specifically interested in the potential of protected areas in conservation and exploring the nature of collaborative management. CYNTHIA SINCLAIR has a Masters in Conservation Biology and is interested in human-wildlife interaction, approaches to sustainable development, livelihood issues in forests, forest governance and its relationship to conservation. She is currently working with the CEPF Western Ghats Program. ADITYA PRITHVI is interested in understanding the effects of income disparity in societies and its effect on perception towards day to day events including wildlife conservation. $\mathrm{He}$ is also interested in the interaction between the various strata of society. RAJEEV RAGHAVAN is interested in interdisciplinary research focused on generating information and developing methods to support decision-making especially in freshwater ecosystems. 